\section{Problems of Participation and Issues of Sustainability in the Public Irrigation System in the Context of Management Transfer: Some Sociological Observations from Eastern Terai, Nepal}

Laya Prasad Uprety

\begin{abstract}
It has been ascertained that participatory processes did not involve learning component from both agency and water users' association for institutional and technical sustainability. The overall process of participation was superficial. There was a need of participation that underscored the empowerment of WUA with accountability. As Vermillion (2005) shares that empowerment with partnership is an emergent institutional paradigm for the irrigation sector development that places water users in the role of irrigation system governance, and government in the roles of regulator and provider of support services. There is a need to re-train the irrigation staff on the emergent institutional paradigm to empower the water users. For the empowerment with accountability, water users are to be provided enough institutional strengthening. There is the need to promote user-agency relationship positively and develop faith and confidence of the users and agency in the regime of transparency. Social scientists point out potential benefits of building successful local organizations. These benefits, for the local people, are in aspects such as empowerment, confidencebuilding, forming social capital, and reduction of dependency. Given the fact that participation is a process, it cannot be achieved in a short span of time with little institutional inputs. Sustainability of the management transferred irrigation systems/sub-systems definitely hinges on the broad-based and inclusive participatory processes.
\end{abstract}

Keywords: participation, sustainability, management transfer, social capital and empowerment

\section{Preliminaries}

This paper dwells on the initial institutional problems vis-à-vis participation and sustainability in the public irrigation system in the context of management transfer. Chhetri (1999) shares that people's participation, putting people first, empowering the locals, bottom-up approach, community participation, etc., have been cited as essential parts of strategies for development or in administering all sorts of programs and projects in Nepal. However, things may not always have been done right while putting such principles into practice which makes many people think that people's participation is perhaps treated more as a rhetoric. People's participation as a concept has gained a remarkable currency in recent years. This is mainly because of its symbolic power as a glossy cover to make plans, programs, and projects attractive. Besides, endorsing people's participation is one good way to assert the legitimacy of a program or project today when there is so much talk about empowering the local people and decentralization. People's participation has been taken a means by the government agencies and projects alike for achieving their goals. It is important to secure people's participation but establishing a problem-free situation of people's participation is not easy. Projects as well as people could easily fall into a situation of co-optation. He quotes Uphoff (1991) who says, “ It is possible that outsiders with funding, may co-opt community leaders, and even ideas, and bend them to outside priorities and perceptions while in the communities, local leaders may co-opt the project efforts when a participatory approach is taken”. Nelson and Wright (1995) share that, "Participation means active, not passive, involvement (of people) and it should be transformative". Chhetri (1999) argues that in practice people's participation is given a variety of meanings similar to the six blind men who debated endlessly on how elements do look like. Chhetri (1996) further argues that the concept of people's participation is not free from a similar form of argument as its proponents and practitioners tend to have a myopic view of what they had perceived. As participation brings many modes and minds, it can be seen as falling along a continuum: coercive at one extreme to volitional at the other end. 
Unlike the conventional technocratic top-down model of irrigation development, there has also been an increasing emphasis on the water users' participation in the recent years for sustainable irrigation management. Groenfeldt (2000) shares that around the world, countries that once promoted more government involvement in irrigation management are adopting new policies that do just the opposite, creating incentives for farmers to take over the management of operation and maintenance, while government agencies focus on improving the management of water at the main system level. There is a strong evidence that the current fad of participatory irrigation management is here to stay and hence, the pendulum that is now swinging toward greater management control by farmers will not soon swing back the other way, toward greater state control. Governments cannot do everything, and there are some things that they are simply not good at doing. Farmers who depend on irrigation water for their livelihoods have the strongest incentive to manage that water carefully. No public sector agency could match the discipline that farmers impose on themselves when they manage their own irrigation systems. He further shares that participatory irrigation management may be even more important in a developing country context for the following reasons: (i) cost-countries incur a high financial and social cost when government agencies assume irrigation management functions that farmers could otherwise handle themselves; (ii) incentives-irrigation users have stronger incentives to manage water productively than does a government bureaucracy, and (iii) efficiency- when management is decentralized to the users, they can respond more quickly to problems or changes in the system.

There is the empirical fact that participatory management approaches are becoming accepted policy in more and more countries. Irandoust and Rijsberman (2005) hold the view that over the past two decades, irrigation sectors in most of Asia shifted their emphasis from development of new irrigation systems to management of existing schemes. During this time, efforts to improve the management and sustainability of irrigation systems in Asia have been considerable. There have been attempts to rehabilitate under-maintained irrigation systems, organize water users' organizations and transfer management of systems to them, collect irrigation service fees, modernize water control systems,

\section{4 | Laya Prasad Uprety}

provide trainings, introduce management information systems and so on.

Sivakoti et.al (2005) have shared that for the last 20 years or so, there has been the growing recognition that irrigation is a multifaceted "socio-technical" enterprise which has had a bearing on the participatory planning and decision-making about irrigation investments, management transfer programs, new approaches towards assistance to farmer-managed irrigation systems, and joint financing of irrigation systems.

With the formulation of the participatory Irrigation Policy (IP) in 1992, the agency-managed irrigation systems in Nepal are undergoing a process of irrigation management transfer. Starkloff et.al (1999) have shared that it typically involves the establishment and training of water user associations (WUAs), the rehabilitation of targeted systems, and the gradual take-over of systems management, partially or fully depending upon size and other factors, by the water users. Generally, the process of management transfer starts with participatory joint management by the Department of Irrigation (DOI) of Nepal and the WUAs. The Asian Development Bank (ADB), World Bank (WB), United States Agency for International Development (USAID) and other donors have supported the policy of management transfer by funding similar projects that include the Irrigation Management Transfer Project (IMTP), Bhairahwa Lumbini Ground Water Project (BLGWP), etc. The WUAs are the perquisite for management transfer and farmer-managed irrigation system (FMIS) rehabilitation programs and they play a central role in the rehabilitation and management transfer processes. Various WUA development and strengthening activities have been and are being undertaken in different irrigation systems in the country. Such efforts are expected to provide them a firm base for their long-term sustainability.

\section{Methods}

The paper is based on the study carried out in the command area of Singeya Minor of Jhumka Sub-Division of Sunsari-Morang Irrigation Project (SMIP), in Sunsari District in 1999/2000. The 
command area is 740 hectares. The area was selected by first making the reconnaissance visit of several similar sub-systems and subsequently, having a consultation with the Project Manager (PM) of SMIP. This Minor was under the participatory joint management (PJM) since 1996 but needed substantial physical and institutional improvements for its sustainability. An attempt had been made in SMIP to improve the situation with the participation of the water users.

In accordance with the 1992 IP, SMIP has been categorized as one to be jointly managed with the participation of the beneficiary farmers. The policy had the aim to turn over the part of the system gradually, covering up to 1000 ha, to the WUA, which would manage the system including the collection of the water charge. In compliance with the policy of the government, WUAs have been established at different levels of the canal system of SMIP.

The operation and maintenance (O\&M) of the sample irrigation sub-system was being jointly managed by the WUA and field irrigation office of SMIP. The Joint Management Agreement (JMA) concluded in 1996 between the project and WUA defined their respective involvement in the management of the system, as well as the process of gradual transfer of responsibility from the former to the latter. According to the JMA, the WUA was responsible for operating and maintaining the on-farm system only. Though the responsibility was gradually transferred to the WUA to the water course in first year, to tertiary level in the second year and then to the sub-secondary level, no significant achievement had been made till the time of field work above the water course level of the canal.

A total of 30 informants mainly from the WUA and community leaders representing the cross-section of the water users' community were purposively selected for gathering the data. An array of data collection instruments/techniques had been used, viz; direct and participant observation, key informant interview, focus group discussion, group interview, informal discussion and review of secondary sources. Given the fact that the data were of the qualitative nature, they were analyzed thematically.

\section{Social Setting}

The social composition of water users of the sample sub-system is heterogeneous, that is, hill migrants (such as the Brahmins/Chhettris, hill-origin indigenous groups of people, traditional occupational caste people, Terai origin caste people and autochthonous Tharus).

\section{Agency's Effort in Organizing the Un-organized Water Users in a Nested Enterprise and Problems of Institutional Sustainability}

With the institutional support of the Association Organizer (AO) and other technical staff of SMIP office, an effort, though perfunctory, was made in organizing the un-organized water users in the command area by helping them to craft an organizational constitution in a standardized format. The newly constituted WUA of Singeya Minor was registered at the office of Chief District officer in the district headquarters of Sunsari as per the regulation of Water Resources Act, 1992.

There existed a two-tiered WUA at the sample sub-system level. The first tier of association formed at the level of 15 water courses was called Water Users' Group (WUG). The second tier of association at the sub-secondary canal level was called Water Users' Co-ordination Committee (WUCC). Though not relevant here, it is contextual to mention here that the Chairpersons of the WUCCs become ex-officio members of the Water Users' Central Co-ordination Committee (WUCCC)-the apex body of the water users of SMIP. These elect one Chairman and one Secretary and the rest become the members of executive committee. All members and officials of executive committee of WUCCs within the command area of SMIP constitute the general assembly. Until April 1999, there were a total of 16 WUCCs of which three are in the command area of first stage, five in the command area of second stage and eight in the command area of third stage of SMIP development. 
There were a total of 15 water courses and each of them had one WUG with five members including a woman representative. Albeit the WUG constitution stipulated that one Chairman and Secretary were to be elected from the General Assembly of all the water users within the command area of water course, they were reported to be elected from among the five farmer representatives. Land ownership and tenancy were the bases of being the members of executive committee at the water course level.

The functionaries of WUG were elected for four years. According to the WUA constitution, the WUG was supposed to discharge the following duties: holding of the two meetings of the general assembly to prepare the plans and programs for the execution; executing the prepared plans and programs by asking budget from WUCC; executing the decisions made by WUCC; preparing the record of the actually irrigated land to submit to WUCC and encouraging the fellow farmers to pay the Irrigation Service Fee (ISF) at the office of WUCC, etc. The constitution also had a provision of the organization of three sub-committees, viz. repair and maintenance, resource mobilization and canal operation, and the underlying objective was to make WUG more active and dynamic for discharging its duties.

The second tier of WUA of Singeya Minor was the WUCC. It was the representative body of its water courses. In other words, the Chairpersons of 15 water courses were the ex-officio members of WUCC. The Chairperson and Secretary were selected or elected democratically from among these ex-officio members. The main functions, duties and rights of WUCC comprised the following: preparing the plans and programs by calling the meeting of general assembly (all members of 15 water courses) and executing them; maintaining co-ordination between and among the 15 WUGs; framing and executing the necessary policies for water charge recovery; helping to solve the water distribution problems of the farmers by maintaining necessary contacts with the irrigation office; encouraging farmers to manage farming systems by adopting appropriate cropping pattern on the basis of water availability; making management for repair and maintenance of sub-secondary and tertiary canal, etc.

\section{8 | Laya Prasad Uprety}

At both levels of WUA, meetings were reported to be dominated by the influential members who usually had greater propensity for the promotion of their personal interests rather than the interests of community of water users living in the command area. Definitely, such processes did discourage the democratic discourse and decision-making at the initial stage of irrigation management transfer.

Provisions in constitution had been made for the organization of three major sub-committees under WUCC which comprised repair and maintenance of sub-co-ordination committee, resource mobilization sub-co-ordination committee, and canal operation sub-co-ordination committee.

The principal problem identified during the field survey was that the organization and function of the different types of subcommittees identified above both at the WUG level and WUCC levels were virtually non-existent. And WUG and WUCC themselves used to do some of the functions of these subcommittees on "as and when needed basis". Neither the WUA functionaries nor the irrigation officials had realized the need for the organization of these sub-committees and their activation to support the performance of WUA. Given the fact that the irrigation officials had helped the water users to craft the constitution based on a standardized constitution, the latter accepted it as having one of the best model. The water users accepted whatever was offered in the process of crafting.

Conversation with the WUG chairman, WUCC Chairman and other members and lead beneficiary farmers revealed the blunt fact that the process of mobilizing water users for the formation of the WUA prior to the turning over of the water courses to them was merely perfunctory. Put in other words, the staff of the irrigation office hastily asked the local farmers to form 15 WUGs and one WUCC and consequently, these organizational entities came into being without broad-based consultation and representation of the generality of the farmer irrigators. Even more simplistically speaking, a few farmers who could come to a meeting place and were also interested formed the WUA because they were asked to do so. A woman was also included as a member in each WUG and 
also in the WUCC. There was a serious problem of broad-based social inclusion in the WUA. Some of the members of the WUA even shared that they had no knowledge of their inclusion in the committee even after three years. Apropos of this, a woman whom the author identified as the member of WUG and wanted to interview about her role in the committee, remarked: "You are the first person to inform me that I am the woman member of the WUG. Neither I had been informed by anyone before this nor asked to attend the meeting. I do not know why the WUG has been formed and I do not know what is my role in it”.

This anecdotal evidence shows how non-participatory was the process of organizing. It further shows how perfunctory was the process. Being based on the impressionistic data, the author has the strong realization that there was more co-optation or enticement of a few elite water users for the acceptance of management transfer. Similarly, the few elite water users (as leaders) might also have the idea to co-opt the project and utilize the social space created by the project in creating/strengthening their political connections (in the form of social capital) vis-à-vis political party leadership, development administration and their local constituency. All this was against the volitional participation (free from state control as Chhetri put in 1999). Definitely, this is not the glib generalization vis-à-vis the process of organizing.

Palacios V. (2000) also shares the importance of promotional activities in the process of irrigation management transfer as in Mexico which was glaringly missing in the case of the sample subsystem. Organizing meetings with the water users by utilizing the existing organizations of farmers such as the existing savings and credit groups, other community-based organizations, etc., (because they would help to set up these meetings) where the potential advantages of the transfer can be explained. There is the need of numerous community workshops and meetings to be held by making the farmers participative and distribution of pamphlets in the community to explain the advantages that management by a users' organization has over management by the government. Svendsen and Nott (2000) have also shared that a defining feature of the irrigation management transfer in Turkey was the initiation of action through existing local organizations and leaders including

\section{$50 \mid$ Laya Prasad Uprety}

the use of local government rather than through the creation of new organizations at the beginning (though its indispensability is there at a latter stage). However, none of these activities were performed in the process of transfer.

Raby (2000) shares that current approaches to participatory irrigation management (PIM) in the Philippines are "synonymous with what is known as the learning process approach". He shares the importance of catalyst approach to water users' organization. Community organizers (college graduates) hired on temporary basis lived in the farming communities and participated in the community activities to gain rapport and acceptance. Over time, they acted as facilitators among the farmers, helping them vocalize their needs, problems, and ideas regarding the irrigation system, maintenance and operation, while informing them of the kind of assistance they could obtain from the government. In this process, the needs that were identified, as well as the type of the assistance to be provided, were tailored to the local farmers and the irrigation system. But when deeper analysis was done in the sample subsystem, such catalyst approach in facilitating the process of institution building was reported to be perfunctorily done. And the lessons from the incremental learning after the transfer process were not used by the irrigation officials in helping the farmers to streamline their institutional performance.

Once the WUA was organized, it could not be active. The water users had the perception that the three factors (as discussed below) have been responsible for triggering the low level of institutional performance of WUA.

\section{i. Participation was imposed.}

A generality of the water users had the perception that participation was imposed on them. Farmers were having the access to the irrigation facility even without being organized and making any contribution (cash/labor).So when they were asked to be organized in the form of WUA and make contribution for the operation and maintenance, the generality of the farmers who were not made participative in the organizing process were unenthusiastic and unwilling for making the desired contribution. Irrigation had been a "free public good" for them ever since the construction of the stage 
1 canal. Contextually, one can view irrigation development as property-creating or property-reproducing process (Coward, 1986). He wrote that collective action is based on property relations, that is, irrigation groups formulate principles of actions and act out irrigation tasks in ways that focus on prior and continuing investments in their hydraulic property. It is this relationship of coproperty holders that legitimizes and activates their solidarity. In this sample sub-system, farmers were found having no sense of ownership- a function of supply-driven model of irrigation development and consequently, had no realization of the relationship of co-property holders. As Vermillion (2005) shared, farmers also had the perception that the whole process was "participation with patronage". Vermillion shared that "participation with patronage" refers to the old irrigation development paradigms of superficial farmer participation in government-controlled programs. There is usually nonsustainability of 'participation with patronage' because the dominant role is played by government bureaucracies in controlling the development process through dependence on donor funds, and perpetuation of farmer dependency on government often resulting in inefficient and inequitable water delivery, sub-optimal productivity, rapid deterioration of infrastructure, and reduced service areas. The main reasons that "participation with patronage" cannot achieve optimal productivity nor sustainability include its failures to give farmers adequate scope or incentives for management; and it does not create a partnership of mutual accountability between the water users and support service providers. Farmers remain inactive after the completion of special projects because of the non-empowerment of WUAs. All this results in the unsatisfactory water delivery (mal-distribution and problem of un-reliable timeliness of water deliveries), chronic underinvestment in maintenance (deferred maintenance), low rates of ISF collections, unabated deterioration, etc.

\section{ii. Inadequate Institutional Strengthening Support}

Related to the above, the roles and responsibilities of the WUA were not properly shouldered by its functionaries and members because they also did not really feel the necessity of participation in the process of institutional performance where water was already available as a "free public good"--a function of the inadequate institutional strengthening support to the nascent WUA. It was shared after four years that a two-day training on irrigation/water management was imparted to the WUA functionaries/members which was virtually inadequate. It was shared that there was no further institutional support until the time of the fieldwork. The generally reported problem of the WUA was the frequent postponement of WUCC and WUG meeting owing to the lack of the quorum (50\%)-a function of the lack of internalization of the roles and responsibilities to be shouldered by the functionaries and members.

\section{iii. Flaw of the Organizational Structure}

It was learnt that there was a flaw in organizing the two-tier WUA of Singeya Minor, that was, the existence of 15 WUGs at water course level and one WUCC at the sub-secondary level. The existing structure had not been very effective in mobilizing the beneficiary communities at the outlet (nos.75) and tertiary (nos.2) levels as it was being practiced in stage 111 in Morang district. There was a need to have a Toli (group) at the outlet level (organized from among the farmers having land within the command area of the outlet), a WUG at the water course level (organized from among the Chairmen/representatives of Toli of the outlets of this command area), water users' committees (WUCs) at tertiary level (organized from among the Chairmen/representatives of the WUGs) and water users' co-ordination committee (WUCC) at the sub-secondary level (organized from among the representatives of WUCs of its command areas).

\section{Lack of Effort to Understand the Community of the Water Users Holistically Prior to the Intervention}

Generally, it is important to understand the traditional social structures, traditional processes of community decision-making, existence of other community-based organizations and their potential role in the management transfer, traditional leadership patterns, cultural diversity, local traditions of community resource mobilization, women's role in community development, etc. A deeper understanding of these socio-cultural variables helps how 


\section{4 | Laya Prasad Uprety}

the intervention has to be made in the community. But no such institutional effort was made in the process of management transfer so that WUA had been virtually ineffective even since its organization.

Given the fact that there were very few short-lived concerted efforts in the initial process of forming the structural social capital (such as the roles, rules, procedures and precedents), there had been very few achievements in a period of four years towards the direction of sustained irrigation management. Similarly, no effort was institutionally made to understand how the cognitive or normative social capital (such as idea, trust, norms and values, beliefs, attitudes, leadership quality, etc) could also be equally important contributing factors in sustained irrigation management.

\section{Irrigation Management Practices and Problems of Sustainability \\ 6.1 Operation}

During the period of the fieldwork in 1999, it was learnt that the operation and maintenance (O\&M) of the irrigation sub-system was reported to be jointly managed by the SMIP and WUA. The long term-term objective was to gradually transfer the maximum responsibility of O\&M to the WUA. But during the period of four years after the onset of PJM, no significant achievement had been made by the time of fieldwork above the watercourse level of the canal - a function of the lack of empowerment of the WUAs and activation of the facilitation processes.

Water distribution-the sum of tasks necessary to ensure that water flowing in the system arrives at the appropriate area at a given time-constitutes operation activity (Hilton, 1990). Water distribution in Singeya Minor, as in other secondary/sub-secondary canals of SMIP, was generally made according to the water requirements of three major crops, namely, monsoon paddy, wheat and Chaite Dhan (early paddy). The standard general practice to start distributing water for the monsoon paddy used to begin from the first/second week of Jestha (May-June) and continued up to the first/second week of Kartik (October-November). Similarly, water for wheat cultivation was distributed from the first of Poush (December-January) to the last of Falgun (February-March).
Similarly, water for early paddy was distributed continuously from the first of Chaitra (March-April) to the last of Jestha (May-June). Under the recommendation of WUCC, three Chaukidars (operatorcum-watchmen) had been locally appointed by SMIP Jhumka Division office who were solely responsible for operating the gates of two tertiaries of Singeya Minor. They were paid Rs. 65 per day by the project office. When there was plenty of water flowing in the canal, there was no need of rotational distribution between tertiaries and among 15 water courses and 75 outlets. But when there was the relative scarcity of water particularly for the paddy transplantation, the WUA used to make a decision apropos of rotational distribution and make an effort to implement to some extent. Though the SMIP office had rated Singeya Minor as one of the best performing sub-systems, the impressionistic and observational data garnered in from the field have identified a myriad of operational problems as explicated below.

\section{i: Dearth of an Operation Schedule}

There was a dearth of an operation schedule at the tertiary and water course level which used to trigger the severe water scarcity in the middle and tail-end locations particularly during the drought period. Though occasional decisions on rotational distribution were made, they were not effectively implemented due to the weakness of WUA. It followed as a corollary that the head-reach farmers used the water excessively at the cost of middle and tail-end farmers who generally expressed their unwillingness to pay water charge on the pretext of water unavailability/inadequacy.

\section{ii: Virtual Non-existence of Field Channels and Haphazard Cutting of Water Course Banks for Unauthorized Outlets}

Another equally critical problem discerned at the farm level was the virtual non-existence of field channels which was diametrically responsible for triggering the problems of water management at the farm level and haphazard cutting of water course banks for unauthorized outlets- a function of the lack of draconian regulatory measure within the existing organizational arrangements of the water users and "sustained" maintenance practice. The field visit had revealed the fact that prior to the turning over the Singeya Minor to the WUA in 1996, farmers had demolished the gated system at the point of each water course-a function of lack of strict 


\section{6 | Laya Prasad Uprety}

supervision by the responsible project staff. The underlying motive of the farmers was to have continuous and unrestricted access to water for irrigation even at the cost of fellow farmer users. Subsequently, the project office replaced the demolished gated structure/system by 9 inch diameter hume pipe structures. Such replacement of gate sans adequate design of water course outlets had negative bearing on the irrigation practices. There was neither control system in water course outlets nor the water equitably distributed among the fields (of the command areas of outlets) the latter being the function of fixing the same nine inch diameter hume pipe structures in all the water courses irrespective of their sizes of command areas. The wrong or improper location of water course outlet pipes at certain places and the lack of field channels had been the principal conducive factors to universal bank cutting of water courses. The problem of bank cutting was found to be on an increasing scale-a function of the lack of draconian regulatory measure within the existing organizational arrangement of the water users and government's failure of modernizing the subsystem up-to field channels.

Given the fact that there was a system of plot to plot or field to field irrigation, every time the farmers having their fields a relatively far from the outlets of the water courses had to seek permission from the fellow farmers having fields close to the water course to irrigate their plots/fields and the latter were generally reluctant to grant permission once their requirements were made. And all this used to create a conflicting situation among farmers on the one hand and impeded the effective water utilization for irrigation crops on the other.

\section{iii: Lack of Knowledge on Crop Water Requirement}

An overwhelming majority of the farmers lacked knowledge on crop water requirement, the head-reach farmers and farmers having land close to water course outlets had a tendency to use water excessively in their fields (as said earlier at the cost of middle and tail-end farmers).

\section{iv: Lack of Communication and Transparency}

Chhetri (1999) shares that information is power. Therefore, sharing information is essential for sharing power. Failing to do so may result in the backfiring of a project's or program's well- intended intervention. There was lack of communication between and among the WUA functionaries and between WUA functionaries and the water users regarding their roles and responsibilities for the effective operation of the irrigation sub-system. Abernethy (2005) shares that communication is one of the principal management skills that are needed in such programs. Support of the members is needed and support cannot be obtained if they do not know what their organization and its functionaries trying to do, and why. Support cannot be expected unless the members feel that their own voices can be heard, and the leadership listens to them, and actually wants to know their view. Leaders must know how to operate a two-way communication system: both informing and listening. This was found to be very poor in the sample sub-system. Abernethy (2005) further shares that transparent behavior of the functionaries/members of the organization is essential because organization must gain collaboration of fellow farmers by persuading them that it is working in their interests, and using its resources wisely. They must, therefore, be able to know what is going on. Transparency depends on effective communication. But there was no transparency of the organizational decisions and financial resources as revealed most of the farmer informants.

\section{v: Drainage Problem}

Equally important was the drainage problem created by the lack of field channels. Due to this drainage problems, some fields received water superfluously and some were completely devoid of water resulting in frequent tensions and disputes among the farmers.

Based on the analysis of the above problems, it can be safely concluded that there was a serious problem in the equity of distribution of irrigation benefits and access to the information-a vital element in the overall decision-making process.

\subsection{Maintenance}

Maintenance is the work required to either keep an irrigation system at or restore to a desired performance level. The objective, therefore, should be: (i) keep the canal system in operating and stable condition at all times in order to assure a dependable supply without any interruption; (ii) restore the canal system to a 
performance level to give a reasonable output; (iii) maximize the life and use of the system facilities, and (iv) avoid high cost of maintenance at latter, due to deferred maintenance. There are, broadly speaking, two categories of maintenance which comprise: (i) preventive (any work required to a keep a system at desired performance level) and corrective (any work required to restore a system at desired performance level) (DOI, 1995).

Since the Singeya Minor was under the PJM, the routine, seasonal and emergency maintenance (barring an exception of demolition to structural works which is beyond the financial and technical capacity of the farmers) at the water course level was institutionally required to be done by the beneficiary farmers themselves. And all these types of maintenance activities at the tertiary and secondary/sub-secondary level were to be done by the SMIP office, that is, Jhumka sub-division office.

Key informants reported that the routine maintenance of the 15 water courses was perfunctorily done by the users themselves at the initiative of WUA. And these routine maintenance activities at the water course level comprised rain-cuts and rain-holes, filling holes created by rats or other burrowing animals, cleaning weeds and other floating trash and promptly removing trees that have fallen into canals. But the observation had the given the impression that farmers had not properly cleaned the weeds grown on the banks for water courses. One could discern grasses/weeds grown everywhere because the WUA had not been able to mobilize the labor of the water users. Hence, there was a lot of deferred maintenance. But such routine maintenance activities at the tertiary and sub-secondary/secondary level were done by the office itself. In addition, replacing missing stone or brick/concrete block as soon as it was sighted, to prevent any further damages, greasing moving parts of the gates, immediate repair of gates that had become nonoperational, repairing excessive leakage through gates and repairing cracks in walls and/ or replacing backfill material where water flows behind a structure, etc., were routinely done by the project office.

The seasonal maintenance (desilting and bank raising) at the water course level at Singeya Minor was also perfunctorily done by the

\section{8 | Laya Prasad Uprety}

farmers at the initiative of WUA. As reported, seasonal maintenance was done twice a year, that is, in Baisak (April-May), and Kartik (October-Novemeber). Generally the maintenance was done in one or two days. The prevailing practice required each household within the command area of each water course contribute one or two day's labor for desilting and bank raising regardless of land size. Though the key informants shared that the absentee landlords were fined one day's wage (Rs 50 then), there was not a single household fined for being absent to contribute labor. Similarly, such households were not strictly deprived of their rights to use water as a result of the infraction of the resource mobilization rule. Field observation gave the ample evidence that the water users had not properly done the seasonal maintenance because one could easily discern the heaps of silts/sand in several places which have contributed to making irregular shapes of the canals. In this case also, the WUA had not been able to mobilize water users' labor for maintenance.

The seasonal maintenance of the tertiary and secondary/subsecondary level was done by the project sub-division office, Jhumka which included fixing of scouring of bank downstream to a structure, repairing of breach of bank of the distributory or minor canal, repairing certain heavy leakage on any canal, etc. The seasonal maintenance was generally achieved by employing causal laborers or contractors during a short closure. The periodical maintenance work, also referred to annual maintenance work, was done by the project office which involved the extra-ordinary work through contractors like replacement or heavy maintenance of structures, excavation of a large quantity of silt in a canal, comprehensive repair of service roads, etc. This category of work was accomplished under the annual program to a project during the annual long closure of the canal system (DOI, 1995). The structural works of water course level were also done by the contractors through project office but farmers often complained their poor quality. The emergency maintenance of the tertiary and secondary/sub-secondary level of Singeya Minor was also done by the project office itself. Certain occurrences that may entail emergency maintenance/repair were: (i) interference by the farmers like unauthorized withdrawal by making holes into the embankment, blocking canal and destroying gates; (ii) careless 
operation of irrigation facilities, and (iii) breaching of canal. Barring an exception to the structural works, other emergency problems at the water course were solved by few farmers themselves to a lesser extent. By and large, there was very little or no modernization of the irrigation structures prior to the turning over to the community of the water users by mobilizing them for the construction of the field channels. Nor the control system was developed at the water course level.

\section{Assessment of Resource Mobilization and Problems of Sustainability}

The rationale of imposing the water charge for the use of irrigation is that it does contribute to meet at least the O\&M cost. The water charge has to be gradually modified as the farmers' ability to pay improves owing to their increased benefit as a result of the project. The imposition of the water charge contributes to the increase of water use efficiency. Like other agricultural inputs, the farmers will consider the irrigation water as an "economic good". It follows as a corollary that the farmers will consume water rationally, which will result in an increase in irrigation coverage and project performance. The payment of water charge is an expression of the confidence of the farmers in the project. The willingness of the farmers to pay water charge arises out of their satisfaction from the irrigation facility, that is, from the project performance. Thus, it is an indicator of participation of the farmers in the project (NEDECO, 1995).

During the fieldwork in 1999, water charge collection in Singeya Minor had been a relatively recent phenomenon. It was included under the PJM in 1996 and since then, water charge collection was also simultaneously commenced for its sustainability. The amount of water charge imposed by the project was Rs. 200 per ha per year which was inadequate to meet the required expenses for the operation and maintenance $(\mathrm{O} \& M)$. It was also determined that there was also very low water charge recovery. Ever since the commencement of PJM, the SMIP office had assigned an Association Organization (AO) for helping the WUA in water charge collection. As per the IP, of the total collected water charge, 50 percent was to be deposited in the central treasury of the government, and remaining 50 percent was to be retained by the WUA for its O\&M. The data furnished by AO in the field showed that of the total Rs. $1,48,000.00$ to be annually collected as water charge from the beneficiaries, only Rs. 27,642.40 ( $18.87 \%$ ) was realized during 1997/98 fiscal year. There has been no congruence between the benefits the farmers had received and the contributions they were supposed to make. As a result, there was the problem of equity in resource mobilization because farmers with free-riding culture had also propensity to reap benefits from the irrigation.

The AO, using the Kisan Lagat (land record book of farmers) used to make a home to home visit for the water charge collection with the help of water users' groups. Generally, the collection was done in five months' time beginning from November to March. Besides making a home to home visit asking for the payment of the water charge, he used to collect it on Sunday, Monday, and Tuesday at the VDC office where the WUA was located. Analogously, collection was done in the command area of the wards of Dumbra VDC on Wednesday, Thursday, and Friday. Field observation had demonstrated that a large majority of the irrigation water users had fallen into arrears in command area of Singeya Minor.

An attempt was made to identify the principal factors behind the low recovery of the water charge. And these comprised: (i) lack of a system of maintaining the proper record of actually irrigated land every year/season; (ii) virtual non-existence of field channels and water inadequacy in the middle and tail-reaches of every water course and farmers' un-willingness to pay the water charge; (iii) non-existence of legal/regulatory mechanism to enforce the water charge collection, particularly to mete out punishments to the defaulters (bigger farmers were reported to be the defaulters who were imitated by the small farmers and WUA could not deprive them of the irrigation facility); (iv) lack of awareness among the beneficiary farmers regarding the importance of the water charge to be used for O\&M of the irrigation system; (v) presence of the defaulting functionaries in the WUA (who were imitated by the unwilling and un-co-operative farmers); (vi) lack of clarity about the institutional responsibilities of WUA among its member farmers; (vi) existence of partisan politics ( If the chairman and other functionaries belonged to one political party, the supporters 
of other political parties were hesitant to pay the water charge as a gesture of no co-operation. Definitely, the local level wayward politicians were reported to be failing in creating a conducive environment for the irrigation rule compliance. They were repeatedly asked for the payment but they used to retort by saying, "The irrigation water is not your ancestral property".), and (vii) proclivity of rampant free-riding culture (The farmers had begun raising the question: why should we only pay the water charge while farmers of the adjoining areas under the command area of agency-managed secondary/sub-secondary were not paying?).

It was shared during the time of the fieldwork that the $\mathrm{AO}$ who was paid Rs. 2180 per month by the SMIP office had been working to help the WUA establish an institutional tradition for the collection of the water charge for its sustainability. He was to be withdrawn within a year because it was not justifiable to retain him there all the times who used to collect the water charge which hardly met his annual remuneration. But the WUA officials shared that they were not in a position to shoulder this responsibility of water charge collection.

Unlike in the sample sub-system, Palacios V. (2000) shares that Mexico has served as a model for other countries considering irrigation management transfer programs which began in 1988 in the wake of favorable policy framework. In a farmer opinion survey, about four farmers out of five indicated they thought irrigation service and maintenance had improved since the transfer. The most dramatic result of transfer has been financial. In the early 1980 s, the government was providing about $80 \%$ of the funds needed for system operation and maintenance. Today the figure is about 25 percent. At the same, irrigation fees have increased more than four-fold. Many associations are branching out into other economic ventures, including credit provision, joint input purchase, and farm equipment rental to members and all this has been attributed to the genuine broad-based mobilization and creation of awareness of the water users in the process of management transfer. If the process of participation is transformative, then the realization of the water charge is not a serious problem because the WUAs are ready to bear the onerous burden.

\section{Concluding Remarks}

It was ascertained that participatory processes did not involve learning component from both agency and WUA side for institutional and technical sustainability. Nor was it thought for its documentation for improving the action. The overall process of participation was superficial. There was a need of participation that underscored the empowerment of WUA with accountability. As Vermillion (2005) shares that empowerment with partnership is an emergent institutional paradigm for the irrigation sector development that places water users in the role of irrigation system governance, and government in the roles of regulator and provider of support services. There is a need to re-train the irrigation staff on the emergent institutional paradigm to empower the water users. At the initial stage, a prolonged institutional support has to be made for the promotional activities for the broad-based social mobilization. For the empowerment with accountability, water users are to be provided enough institutional strengthening. There is the need to promote user-agency relationship positively and develop faith and confidence of the users and agency in the regime of transparency. Farmers in the sample sub-system were not supportive of their organization because they were not aware of the need of the viable organization as promoted by the local initiatives. But as Abernethy (2005) suggests that, in order to establish a viable organization, the official side must respect the irrigation users, and identify along with them some set of objectives that are sufficiently interesting to them (the farmers), in order to ensure that they will feel supportive to their own organizations. Social scientists point out potential benefits of building successful local organizations. These benefits, for the local people, are in aspects such as empowerment, confidence-building, forming social capital, and reduction of dependency. Given the fact that participation is a process, it cannot be achieved in a short span of time with little institutional inputs. Sustainability of the management transferred irrigation systems/sub-systems definitely hinges on the broadbased and inclusive participatory processes. 


\section{References}

Abernethy,C.L. (2005). "Can Programs of Irrigation Management Transfer be Completed Successfully?” in P.Pradhan and U. Gautam (eds.) Farmer-Managed Irrigation Systems and Governance Alternatives.Proceedings of the Third International Seminar Held on 9-10 September 2004, Kathmandu, Nepal (pp.32-60).

Chhetri, R.B.(1999). “The Rhetoric and Realities of People's Participation in Conservation and Development in Nepal: An Anthropological Perspective” in R. B. Chhetri and O.P Gurung (eds.) Anthropology and Sociology of Nepal: Cultures, Societies, Ecology and Development ( pp.192211). Kathmandu: SASON.

Chhetri, R.B.(1996). "Blind Men and the Elephant” Habitat Himalaya 3(2):1-2.

Coward, E.Walter, Jr. (1988). "State and Locality in Asian Irrigation Development: The Property Factor” in K.C Nobe and R.K. Sampath (eds.) Irrigation Management in Developing Countries: Current Issues and Approaches. Boulder: Westview Press.

Department of Irrigation (DOI) (1995). Sunsari Morang Irrigation Project: Project Preparation Plan (POP) for Sunsari Morang Irrigation Project. Kathmandu.

Groenfeldt, D. (2000). "Introduction: A Global Consensus on Participatory Irrigation Management" in D. Groenfeldt and M. Svendsen (eds.) 2000. Case Studies in Participatory Irrigation Management (pp.1-2). Washington, D.C: World Bank Institute.

Hilton, M.R.(1990). Cost Recovery and Local Resource Mobilization in Irrigation System in Nepal. A Case Study of Karjahi Irrigation System. A Paper Presented at the First International Meeting of International Association for the Study of Common Property.

Iranduoust, Said and Rijberman, Frank.(2005). "Foreword” in G.P. Shivakoti, D.L.Vermillion,Wai-fung Lam, E. Ostrom, U.Pradhan, and R. Yoder (eds.) Asian Irrigation in Transition: Responding to Challenges (pp.13-14). New Delhi: IWMI and Sage Publications.

NEDECO Consultants, (1995). Program of Water Charge

\section{$64 \mid$ Laya Prasad Uprety}

Collection, 1995-96. Kathmandu.

Nelson, N and Wright, S.(1995). "Participation and Power" in N. Nelson and S.Wright (eds.) Power and Participatory Development: Theory and Practice (pp.1-18). London: Intermediate Technology Publication.

Palacios V., Enrique. (2000).” Benefits and Second-Generation Problems of Irrigation Management Transfer in Mexico" in D. Groenfeldt and M. Svendsen (eds.) 2000. Case Studies in Participatory Irrigation Management (pp.3-26). Washington, D.C: World Bank Institute.

Rabby, N.(2000). "Participatory Irrigation Management in the Philippines: National Irrigation Systems" in D. Groenfeldt and M. Svendsen (eds.) 2000. Case Studies in Participatory Irrigation Management (pp.1-2). Washington, D.C: World Bank Institute.

Shivakoti, G.P. Lam, Wai-fung, and Pradhan, U. (2004) “Asian Irrigation Problems and Prospects" in G.P. Shivakoti,

D.L.Vermillion,Wai-fung Lam, E. Ostrom, U.Pradhan, and R. Yoder (eds.) Asian Irrigation in Transition: Responding to Challenges (pp.21-44). New Delhi: IWMI and Sage Publications.

Starkloff, R, Upadhyay, S, Hemchuri, H, and Prasad, K.C. (1999). Functional Status of Panchkanya Water Users Association Nepal. Kathmandu: Department of Irrigation, and International Water Management Institute.

Svendsen, M. and Nott, G. (2000). "Irrigation Management Transfer in Turkey: Process and Outcomes" in D. Groenfeldt and M. Svendsen (eds.) 2000. Case Studies in Participatory Irrigation Management (pp.27-88). Washington, D.C: World Bank Institute.

Uphoff, N.(1991).”Fitting Projects to People” in M. Cernea (ed.),Putting People First: Sociological Variables in Rural Development (pp.457-511). New York: Oxford University Press (Second Edition).

Uprety, Laya Prasad.(1999). Sociological Analysis of Irrigation $O \& M$ and Water Charge Recovery Study of Singeya Minor, Sunsari Morang Irrigation Project. A Report Submitted to CMS/ROYDS, Lalitpur, Kathmandu, Nepal.

Water Users' Co-ordination Committee, (1996). Constitution of Singeya Minor. Sunsari 